\title{
Industry Consolidation and Network Evolution in U.S. Global Banking, 1986-2004
}

\author{
Eric J. Neuman \\ Department of Business Administration \\ University of Illinois at Urbana-Champaign \\ eneuman@umich.edu (will update once I have received my uiuc.edu address) \\ Gerald F. Davis \\ Ross School of Business \\ University of Michigan \\ gfdavis@umich.edu \\ Mark S. Mizruchi \\ Department of Sociology \\ University of Michigan \\ mizruchi@umich.edu
}

\begin{abstract}
This paper analyzes the relations among bank mergers, changes in boards and their networks, and changes in the global footprint of merging banks. We examine all mergers involving U.S. banks with foreign branches between 1986 and 2004. We find that while the largest banks have become even larger through mergers, their boards have stayed roughly the same size with the same pattern of connections, leaving banks relatively less central in the intercorporate network. And while global banks previously had more globally-oriented boards, this is no longer the case, as the link between board networks and strategy has become more tenuous. Because global banks were particularly prone to merging, the average commercial bank in the U.S. is now far more domestically-oriented than firms in most other industries. American banks have thus become more domestic at the same time that the rest of American industry has grown much more global.
\end{abstract}

In Advances in Strategic Management 25: 213-248. 
Banks had networking strategies long before anyone in business used the term network. In 1914, Louis Brandeis described the "endless chain” created when banks such as JP Morgan \& Co. sent their officers to serve on the boards of client firms (Brandeis, 1914). The largest banks' executives collectively served on dozens of corporate boards. George F. Baker of First National personally served on 22 boards—-far outpacing even Vernon Jordan in his heyday. Bankcentered networks were not limited to the United States. In describing the contemporary German system, Lenin (1916: 41-42) stated that "a very close personal union is established between the banks and the biggest industrial commercial enterprises...through the acquisition of shares, through the appointment of bank directors to the Supervisory Boards (or Boards of Directors) of industrial and commercial enterprises, and vice versa.” Banks provided one-stop-shopping for control of industry, a finding with real practical value for a prospective chief executive with Lenin's orientation. In the U.S. and elsewhere, banks continued to hold their central position for decades, their boards comprised of executives from the best-connected corporations and nonprofits (Mizruchi, 1982). Whether as a means to gather high-level intelligence to guide investment choices (Mintz \& Schwartz, 1985) or a device to signal legitimacy to prospective corporate clients (Davis \& Mizruchi, 1999), board networks were central to bank strategies for most of the twentieth century.

Since the early 1980s, there have been fundamental changes in the banking industry. Advances in information and communication technologies, deregulation, and the consequent expansion of financial markets have undermined the need for commercial banks, as creditworthy borrowers increasingly turned to financial markets for debt. Consolidation of the banking industry, long prevented by the peculiarities of America's federal system of regulation, began in earnest in the 1990s. Banks responded to new opportunities and challenges in diverse ways, 
including geographic expansion and industrial diversification. Some, such as NationsBank (now known as Bank of America) and Bank One, went on acquisition binges, growing from regional to super-regional to near-national, with a focus on operating retail branches in ever-broader territories. Others, such as Mellon Bank and Bankers Trust (the latter now owned by Deutsche Bank), diversified into businesses such as investment banking and mutual funds. And still others, such as Citibank and the Bank of Boston, expanded their reach into global markets, by buying or expanding branch networks outside the U.S. Sometimes these strategies collided, as the largest banks were folded into an elite group of mega-banks. NationsBank, for examplepreviously a primarily domestic institution based in North Carolina—ended up with a vast network of overseas branches due to its acquisitions of BankAmerica and FleetBoston.

Prior work suggests that networks are both a cause and a consequence of bank strategies. As banks retreated from the corporate lending business during the 1980s and 1990s, they also shrank their boards and curbed their traditional practice of recruiting "celebrity directors" (Davis \& Mizruchi, 1999). Having a well-connected board was a consequence of pursuing a strategy of lending to business. As commercial banks adopted a more financial service-oriented approach, their boards came to look more like those of investment banks. Once in place, however, a board can have a considerable influence on strategy. Well-connected banks, for example, were quicker to globalize in the 1960s than their more peripheral peers, suggesting that so-called celebrity directors brought actionable intelligence to bear on bank decision making (Mizruchi \& Davis, 2004).

In this paper, we link networks and strategy in the context of the ongoing bank merger wave. ${ }^{1}$ We are particularly interested in understanding how the global footprint of American

\footnotetext{
${ }^{1}$ Because we believe that all mergers involve an acquiring and acquired entity, we use the terms "merger" and "acquisition" interchangeably. Although some arrangements, such as when First Chicago and NBD became First
} 
banks has changed as the number of participants has declined. Several of the most venerable names in global banking have disappeared or shifted identities, leaving only three significant players in the global market: Citibank, JP Morgan Chase, and Bank of America. We address four questions: First, do the boards of global banks look different from those of domestic banks? Second, how do boards of global banks change after an acquisition? Third, how has the position of global banks in intercorporate networks changed as a result of industry consolidation? And fourth, how does the composition of the board influence a bank's approach to globalization following mergers? In addressing these questions, this paper contributes to understanding the organizational dynamics underlying financial globalization and the link between networks and strategy, especially with regard to firm-level and industry-level endogenous drivers of network change. Consistent with Amburgey et al. (2008) and Hite (2008), we show the changing nature of network ties and structures over time. Our findings also provide an informative contrast with those of Conyon and Muldoon (2008), who show that financial institutions continued to play a critical role in the intercorporate network in the UK as late as 2000.

\section{U.S. BANKS AND GLOBALIZATION}

Until very recently, financial institutions in the United States were fragmented both geographically and industrially. Geographically, commercial banks (that is, banks that gather deposits from savers and lend funds to businesses and other borrowers) were organized on a state-by-state level and regulated both by the Federal Reserve Bank (a national entity) and statelevel officials. Despite having names like “Bank of America,” from 1832 until the early 1980s,

Chicago NBD, are announced as a "merger of equals," we believe that these statements are face-saving tactics used to placate the employees, customers, and shareholders of the acquired entity. By examining characteristics of the surviving firm such as its CEO, board, and headquarters, one can almost always determine the role of each party in an arrangement that was announced as a merger. 
banks (with rare exceptions) did not operate branches in more than one state within the U.S., and many states limited local banks to only a single branch (Marquis \& Lounsbury, 2007).

Geographic regulation was eased in the 1980s, and in 1994 the Riegle-Neal Act lifted restrictions on interstate banking, prompting a substantial industry consolidation that created "superregional” banks.

Until recently, commercial banking (accepting deposits and making loans) had been strictly separated from investment banking (underwriting securities, buying and selling stocks and bonds) and insurance by the Glass-Steagall Act of 1933. Banking laws passed during the U.S. Civil War (in 1863) created a national currency and prevented nationally-chartered banks from owning stock. Commercial banks became increasingly involved with investment banking during the early part of the twentieth century, and by 1930 nearly half of new securities offerings went through affiliates of commercial banks. This intertwining was blamed by some for worsening the Great Depression; Glass-Steagall, which was passed during this period, forbade commercial banks from owning and dealing in securities. Thus, Morgan Stanley (an investment bank) split off from JP Morgan (which became exclusively a commercial bank). Despite years of debate and efforts by banks for repeal, Glass-Steagall stayed in effect until 1999. Commercial banks such as JP Morgan and Bankers Trust were granted exceptions by the Federal Reserve Bank for brokerage and bond underwritings beginning in the 1980s and early 1990s, while conversely some investment banks were allowed to do commercial lending beginning in 1994 . Glass-Steagall was finally repealed in 1999 in the wake of the merger between Citicorp and Travelers (an insurance company that also owned Salomon Smith Barney, a large investment bank). Citigroup, as the new firm was named, subsequently spun off its insurance business. 
American banks followed a distinctive path to globalization compared to banks in Europe and elsewhere. London grew to become a major international financial center during the Victorian Era, and by the turn of the twentieth century it was home to outposts of dozens of foreign banking houses, including Schroder, Rothschild, Kleinwort, and JP Morgan. Indeed, finance continues to serve an outsize role in the British economy as other sectors of industry have faded (cf Conyon \& Muldoon, 2008). Amsterdam also served as a global financial center, along with a number of other trading capitals. In contrast to their European counterparts, nationally-chartered American banks were not allowed to open overseas branches until 1913, although other forms of foreign business were allowed. As late as 1960, only eight U.S. banks had any foreign branches (led by Citibank’s predecessor, First National City Bank)—a stark contrast with American manufacturers and oil companies, which had administered expansive global operations for decades.

The domestic orientation of American banks changed in the late 1960s and 1970s, as the banks rapidly expanded their overseas operations. A number of causes were behind this timing. First, a tight money supply made it attractive to gather "Eurodollar” deposits via London branches. $^{2}$ Second, some banks followed their large clients overseas to capture the clients’ nondomestic business. Third, by the mid-1970s, leading banks were making roughly half their profits overseas, and Chase Manhattan was earning more than three-quarters of its profits outside the U.S. (Hallow, 1993). This encouraged other banks to follow the example set by Citibank and Chase, and by 1980, 150 of them had overseas branches, spanning dozens of countries. The foreign assets of U.S. banks increased one-hundredfold between 1960 and 1980, and even the smallest banks often had foreign branches. To take one example, Colonial Bank of Waterbury,

\footnotetext{
${ }^{2}$ Eurodollars are U.S. currency held in banks outside the United States, including, for example, foreign profits of American multinationals.
} 
Connecticut (1980 population: 103,266) operated branches in the Cayman Islands (1974-1985) and in London (1981-1983), despite being only the 152nd largest bank in the United States in 1980.

The industry suffered a dramatic reversal of fortune in 1982 following the Mexican debt crisis. American banks had come to be among the predominant lenders to low-income countries, replacing states as the largest source of funds. By 1982, these banks had extended billions of dollars of loans to states whose capacities to repay them were questionable. In late 1982, Mexico suspended its debt payment, leading to a contagion of default among Latin American countries and a crisis for their creditors. The subsequent period is known as "the lost decade" in economic development circles, as capital flows to low-income countries abruptly halted, ultimately to be replaced with market-based financing (Larosiere, 2005). By the end of the decade, the banks that had been the most aggressive globalizers were those hardest hit. Congressman John Dingell claimed in 1991 that Citibank was "technically insolvent” and "struggling to survive.”

American banks responded to these crises by retrenching, beginning an exodus from overseas branching that lasted from the early 1980s into the mid-1990s. As Figure 1 shows, the number of foreign branches of U.S. banks declined steadily from 1986 through 1994. The decline in the number of U.S. banks with at least one foreign branch was even sharper. As Figure 2 demonstrates, this decline was especially pronounced in the late 1980s and early 1990s.

$<$ Figures 1 and 2 about here >

Prospects for international banking appeared to improve in the mid-1990s, however. As Figure 1 illustrates, the mid- to late-1990s saw the total number of branches rise sharply, peaking 
at 814 in 2000 (although the number of banks with foreign branches continued to decline, albeit more slowly than in earlier years). A number of geopolitical changes took place in this era that in theory offered U.S. banks new venues for business. The dissolution of the former Soviet Union, the opening of markets such as China and Vietnam, and the vast expansion in crossborder trade all created opportunities for American banks to expand their global operations. Yet, as Figure 3 illustrates, the number of countries in which U.S. banks operated rose and fell rather modestly during this period, varying between a low of 69 in 1992 and a high of 78 in 2000. The list of countries entered during this period, shown in Table 1, provides little clear evidence that these new opportunities were the driving force behind this brief expansion in overseas branching. Entry into China (1987), Russia (1995), South Africa (1995), Vietnam (1995), and Bulgaria (2000) appear alongside New Zealand (1987), Australia (1994), Canada (2000), and Israel (2000) — countries for which there was no obvious exogenous explanation for entry.

$<$ Figure 3 about here $>$

$<$ Table 1 about here $>$

A closer examination reveals that much of the growth in the industry resulted from increased contestation between large, internationally-focused banks in areas of existing operation. Most of the expansion came in the form of additions to banks' existing branch networks, particularly in South America. For example, Argentina witnessed the equivalent of a branching arms race between Citibank and Bank of Boston. Between 1996 and 1999, Citibank grew from 45 to 96 branches (a 113 percent increase) and Bank of Boston from 44 to 139 
branches (a 216 percent increase). These new Argentinean branches alone account for 87 percent of the overall growth in foreign branching during this period.

Focusing on the number of banks operating foreign branches helps clarify some of these changes. Figure 2 shows that the number of banks with foreign branches monotonically decreased from 46 in 1986 to 22 in 2004. As Figure 4 shows, this decline in the number of banks led to an increased concentration in the proportion of foreign branches operated by the three most involved banks. By 2004, just three of the remaining 22 banks with foreign branches accounted for over 85 percent of the total branches.

$<$ Figure 4 about here $>$

While these changes in foreign branch banking were happening, the banking industry's consolidation began in earnest. The number of banks declined from over 10,000 in 1986 to under 7,000 in 2000, while the concentration of assets increased substantially. What was particularly striking in this movement was that much of the consolidation happened among the very largest banks, including those that were most globally-oriented. Figure 5 shows the family trees of the three largest banks, which emerged from 13 already large banks in just 14 yearsbetween 1990 and 2004. Notably, all of the pre-merger constituents except Bank One were among the most significant international banks in the United States.

$<$ Figure 5 about here $>$ 
This merger movement provides a fruitful context within which to understand the changing shape of bank globalization. We shall do this by examining the pre- and post-merger strategies of merging global banks.

\section{THEORETICAL CONSIDERATIONS}

We have described two colliding forces in the 1990s: consolidation of the banking industry, and conflicting pressures around globalization. We argue here that the bank consolidation movement is an informative context in which to unpack the reciprocal role of networks and strategy in driving the process of corporate globalization. That is, mergers among banks, which may be based on divergent strategies, provide a context in which to explore how networks shape-and are shaped by—strategic moves. In this section, we describe some of the theoretical accounts given for banks’ global expansion and retrenchment; the place of board networks in strategy; why branch networks are an apt place to examine the effects of consolidation; and how we approach the merger movement.

We first provide a word on why we study bank branching as our primary outcome measure. Although there are several ways in which a bank can operate in a foreign countryincluding contracting with other banks to act as agents (known as correspondent banking), opening a representative office, or creating a foreign subsidiary_-branching is perhaps the most significant commitment to a market. Branches can do "banking proper," that is, taking in deposits and making loans, and they are legally part of the parent bank. Thus, their contributions show up on the parent company’s balance sheet: deposits gathered by branches can be used elsewhere in the world, and branches can draw on the capital of the parent bank to make loans. 
As such, we see branches as the most consequential presence of a bank, and a suitable measure of overseas expansion by banks.

Why did American banks globalize their branch networks as they did? Prior research gives a number of possible accounts for U.S. banks' initial forays into foreign markets, and how they ended up where they did (see Mizruchi \& Davis, 2004). The first account is that banks followed their customers. Just as vendors in the Japanese auto industry mirrored the locational choices of their major customers (Martin, Swaminathan, \& Mitchell, 1998), banks might follow their corporate clients overseas, the better to meet the clients’ needs. Given the peculiar Federal regulation of American banking, we might expect to see Detroit banks locating branches near automakers’ foreign plants, or St. Louis banks opening branches near beer and pet-food manufacturing facilities. National City Bank of Minneapolis, for instance, was founded in 1964 by Lowell and Dwayne Andreas, who in 1972 went on to run agricultural giant Archer Daniels Midland (while maintaining seats on the National City board). Archer Daniels Midland developed significant interests in Eastern Europe, so it is more than a coincidence that in 1979 National City became the first_ — and so far only_-American bank to operate a branch in Hungary. This branch was closed immediately after National City was acquired by M\&I Bank in 2001.

A second possible reason for banks’ opening of foreign branches is that the banks' board members might have interests in or knowledge of particular countries. Although a bank’s directors are often local business executives, their companies may or may not be customers of the bank. Nonetheless, such individuals can provide generic business intelligence about the attractiveness of different foreign markets. 
Third, some observers have suggested that banks followed their competitors into particular markets. Banking folklore holds that Walter Wriston of Citibank was almost singlehandedly responsible for the globalization of American banking, and as we noted earlier, the vanguard banks found overseas banking highly profitable during the 1970s. Mizruchi and Davis (2004) found that as highly central banks moved overseas, other central banks were those most likely to follow. Given that the most well-connected banks were likely to see one another as competitors as well as peers, the finding suggested that banks might have been following their most direct competitors in establishing overseas branches (Henisz \& Delios, 2001).

Although several accounts exist for banks' decisions to open foreign branches, the reasons for banks' decisions to "de-globalize” have received little attention. In fact, we are unaware of any theory of "strategic retrenchment" associated with the decline in overseas branching. One way to consider the issue of de-globalization is to assume that it is simply the converse of globalization: as a bank's customers reduce their foreign operations, for example, one might expect the bank to follow suit. The problem with this account is that for most American businesses, globalization followed a monotonically non-decreasing pattern: the average foreign sales of U.S. companies — outside of those in a few service industries (such as retail) or intrinsically local industries (such as utilities)—has risen virtually every year since the 1980s. There is little sign that companies outside of banking have been abandoning their foreign operations en masse.

An alternative possibility is that banks may have simply been out-competed outside their domestic markets. One of the unintended consequences of American bank globalization is that the American banks trained a generation of their own competitors. While the World Bank notes the benefits to foreign markets of hosting U.S. banks, in part due to the fact that American 
bankers can train those in the host nations, the other side of this story is that the local bankers trained by American banks can create effective local competitors to their former employers. This suggests that the longer a branch operates, the more likely it will be to generate its own competition.

There is one phenomenon, however, that has been shown to influence banks' decisions to open foreign branches, and that we believe might also have played a role in their decisions to retrench: the banks' network ties, as indicated by their connections to other firms through their boards of directors. Corporate boards and the networks they create play a role, we argue, in both reflecting and shaping bank strategy. Board interlocks have been shown to affect strategies among a wide range of non-financial corporations, from acquisitions (Haunschild, 1993) to takeover defense policies (Davis, 1991) to philanthropy and political activity (see Mizruchi, 1996 for a review of the literature on interlocks). These effects may be even more pronounced among banks. Mintz and Schwartz (1985) noted, for example, that banks recruit executives and other directors from well-connected corporate boards specifically to guide their broad investment choices. Bank boards are much larger and better-connected than other boards, Mintz and Schwartz argued, because they provide high-level intelligence on broad trends in industry, what Useem (1984) called “business scan.” Thus, although directors might not be in the trenches giving advice on particular loans or on the adoption of specific strategies, they can provide insight into long-term trends affecting business through their service on other boards. In the realm of globalization, this might take the form of advice about specific countries or regions (as in, for example, "Newly wealthy businesspeople in Malaysia like American brands, and might be a good market for asset-gathering”). Banks with more globally-oriented directors may thus be 
more prone to expanding or maintaining global operations themselves. Similarly, banks seeking to globalize may be more likely to recruit directors from global businesses.

In the same way that interlocks might have affected banks' decisions to open foreign branches, they might also have affected the banks' decisions to close those branches. Just as a bank’s CEO might hear of overseas opportunities from a director at a board meeting, he or she might also be exposed to information suggesting that a country is an unsuitable place to conduct business. Although we believe that such events occurred and may explain some of the retrenchment that American banks experienced, there is another process that we believe may have been more important: the extensive merger activity among banks over the past two decades. This merger activity, we suggest, provides a context in which the networks within which banks were situated affected their behavior.

Mergers are a particularly appropriate context for examining the link between networks and strategy. As we have seen, strategies may lead to the creation of networks, through the recruiting of directors. At the same time, networks may also lead to the development of strategies, given that a firm's directors can shape the firm's strategic direction. Mergers are a punctuating event in this process, a stock-taking for strategy. First, when large banks merge, the resulting entity—including its board—is typically a hybrid. The board of JP Morgan Chase, which resulted from the mergers of Manufacturers Hanover, Chemical, Chase Manhattan, and JP Morgan, included directors from each of its predecessors. Who stays and who goes after the merger is a reflection of the new entity's priorities, and is thus indicative of the strategy of the new firm. Second, mergers bring to the forefront the question of which facilities will stay and which will be jettisoned. For banks, this includes decisions about the establishment, maintenance, or closure of particular branches, including those overseas. We anticipate that 
changes in firm strategies resulting from a merger will be observable within approximately two years.

Our research strategy, then, is to examine the boards and global branch networks of merging banks before and after the merger to explore how consolidation affects globalization (or the reduction thereof). Specifically, we are interested in the ways in which board networks and branch networks mutually influence one another.

\section{DATA}

Sample. We operationalize global banks as all publicly-traded, U.S.-based commercial banks that operated at least one foreign branch (outside the Bahamas and Cayman Islands) between 1986 and 2004. There were 68 such banks. In our analysis specific to merged banks, we included only banks that had at least one foreign branch and that engaged in a merger, as either the acquiring or target firm, between 1986 and 2004. This criterion yielded a total of 37 banks, spanning 23 mergers. These mergers are listed in the table in Appendix A. The total number of banks is less than two times the number of mergers because several banks engaged in more than one acquisition.

We selected 1986 as our starting point because previous work has established this as the dawn of the bank merger wave (Rhoades, 2000). We end our analysis in 2004 to allow time after the acquisition for the acquiring bank to decide what to do with its acquired branches.

Board data. One component of our analysis involves a comparison of the network centrality and board size of global banks versus non-global banks and non-bank firms. For this analysis we collected data on the boards of all corporations traded on the Nasdaq and the New York Stock Exchange in 1987, 1992, 1997, and 2002, as compiled by Compact Disclosure. This 
includes 3,736 firms (with a total of 34,468 directors) in 1987; 3,658 firms (with 32,434

directors) in 1992; 5,715 firms (with 45,582 directors) in 1997; and 4,760 firms (with 39,992

directors) in 2002. For before-and-after comparisons of merging banks, we used proxy

statements filed with the Securities and Exchange Commission (SEC) as well as annual reports

and Compact Disclosure when proxy statements were unavailable.

Branch data. Branch data came from the Federal Reserve Board following a Freedom of Information Act request. We submitted to the Fed identifying information for each branch operated by a U.S. bank between 1986 and 2004. ${ }^{3}$ In response, we received information on (a) the branch start date and, if applicable, the branch end date; (b) the branch location (including the address, city, and country); and (c) parent bank identification information, including any changes in ownership, for 1,447 branches owned by the aforementioned 68 global banks.

Corporate data. Corporate data, including information on bank financial characteristics and geographic segment data for non-financial firms, came from the Compustat database, accessed via WRDS. Specifically, the geographic segment data were used to calculate the amount of international experience that each outside director of a particular bank had at his or her own company. We operationalize a global board member as one whose company has international sales comprising at least 10 percent of its total sales.

Merger data. Merger data were gleaned from the Federal Reserve Board, the Federal Financial Institutions Examination Council's National Information Center, and archival searches of press releases and articles in the popular press. We recorded the names of the acquired and

\footnotetext{
${ }^{3}$ We originally obtained identifying information on every U.S-operated foreign branch from the Federal Financial Institutions Examination Council's National Information Center (NIC) (http://www.ffiec.gov/nicpubweb/nicweb/NicHome.aspx) using a web crawling computer program written by the first author in October 2005. This search did not include identifying information on the branch's parent bank, which necessitated the use of the Freedom of Information Act request. Unfortunately for researchers interested in this topic, the NIC has redesigned its web site since 2005 and made it impossible to access historical data on foreign branches of U.S. banks.
} 
acquiring bank of each merger, information on the surviving bank, and the date of the merger. These data also appear in Appendix A.

\section{FINDINGS}

\section{How are the Boards of Global Banks Different?}

Table 2 presents a comparison of the size and two centrality measures-degree (the number of interlocks) and eigenvector centrality—of global banks versus non-global banks and non-financial corporations. The data in Table 2 indicate that global bank boards were strikingly different from other boards in 1987. First, the boards of global banks were much larger: the median-sized board of a bank with at least one foreign branch had 18 members in 1987, compared to 12 for non-global (or “domestic") banks and 8 for non-financial firms. Second, the boards of global banks were far more central than those of non-global banks or non-financial firms. The median eigenvector centrality of global banks was 4.59 , compared to 0.14 for both non-financial firms and domestic banks, indicating that the directors that global banks recruited served on more central boards than those recruited by domestic banks. In data not shown in Table 2, global banks had an average of 5 “received ties” (that is, executives of outside firms) compared to 2.3 received ties for non-isolate domestic banks. The median degree centrality (the average number of total ties) was also far higher among global banks (21.5) than it was for nonfinancial firms (2) and domestic banks (1).

$<$ Table 2 about here $>$ 
Perhaps most importantly from our perspective, we find that the outside directors serving on bank boards came from more globally-oriented companies: the average foreign sales of global bank directors' home companies (also not shown in the table) was 11.9 percent in 1987, compared to 8.4 percent for domestic banks. Cumulatively—given that global banks had substantially more received ties—-the outside directors of global banks had significantly greater “global experience.”

\section{How do Bank Boards Change in the Context of Mergers?}

When one bank acquires another, there are a number of theoretically plausible strategies that the surviving bank could follow when selecting its board members. One possibility is to keep all board members from both banks. This “keep them all” strategy, especially if applied over repeated acquisitions, would yield an extremely large, ultra-central board. The opposite approach would be for the acquiring bank to demonstrate its control over the post-acquisition bank by keeping only directors from its own board. In between these two extremes, the acquiring bank could add to its own board a few select directors from the acquired bank's board, possibly to smooth over tensions related to the acquisition but also because those directors may be highly respected or provide the acquiring bank with insight into the affairs of the acquired bank. Yet another option would be for a more equitable split between the banks, with approximately half of the surviving board coming from the board of each bank in the merger. This approach gives the best appearance of a "merger of equals" and also allows the acquiring bank to reinvigorate its board with new relationships and new ideas.

We find that among mergers of global banks, the "equitable split" and "acquiring control” strategies are dominant. Of the mergers listed in Appendix A, the vast majority adopted 
one of these two approaches. (Two mergers-RepublicBank acquiring Interfirst and Bank of America acquiring Security Pacific_can be characterized as "keep them all”, though the massive boards that resulted did not last long. Each surviving bank’s board was reduced by at least $50 \%$ over the next two years.) This is consistent with the findings in Table 2 that the board size across global banks slightly decreased over our period of study.

$<$ Figures 6 and 7 about here $>$

As an illustration of how these strategies are applied, in Figure 6 and Figure 7 we depict the board composition histories of Bank of America and JPM Chase, the two banks responsible for most of the substantial mergers in our sample. Each bank acquired four other banks during our sample period and at one time or another each employed the two dominant strategies for adding directors from acquired banks. Furthermore, in the years between their acquisitions both banks allowed their board sizes to decrease through attrition. The banks therefore exhibit a surprisingly similar pattern of waxing and waning of their boards over this 21-year period. The banks differ, though, in how long their acquired directors remained on their boards. Bank of America added 29 directors from banks it acquired, and the 22 who had left by 2007 did so after an average of 2.8 years. Of the 32 acquired directors that JPM Chase added, the 23 that have since departed averaged 4.9 years of service. This culminates in substantial differences in the final composition of the two boards. Upon its fourth acquisition, Bank of America's acquired directors remained a minority (9 of 19 directors). For JPM Chase, the situation was the opposite; after its fourth acquisition, only 3 of the 16 directors on JPM Chase’s 2004 board had never served on the board of one of the banks that it acquired. 


\section{How does the position of global banks in the intercorporate network change?}

Table 2 also shows that as the merger movement surged through the industry, the boards of global banks remained distinctive from boards of domestic banks and of non-financials. Although the size and centrality of global banks’ boards decreased slightly over time, by 2002 the boards of global banks were still far larger and more central than both their domestic counterparts and non-financial firms. The boards of the global banks remained nearly twice as large as those of domestic banks (a median size of 18 vs. 10) and more than twice as large as non-financial boards (18 vs. 8 ). As in the earlier years, the centrality of global banks remained far above those of domestic banks and non-financials.

Changes in the network position of global banks are also illustrated in Figure 8 and Figure 9, which show the received-tie networks of global banks in 1987 and 2002. Node size is indexed to the extent of a firm's foreign operations. For banks, this represents the size of the foreign branch network. For non-banks, the size of the node reflects the percentage of the firm's sales from outside the U.S.

$<$ Figures 8 and 9 about here $>$

Two things are notable about these figures. First, in 1987, there is a strong correlation between the magnitude of a bank's foreign branch network and the average level of foreign operations of its received ties. This was no longer true in 2002. In the earlier period, the more global banks recruited directors from more globalized firms (or at least executives of U.S. firms with more international revenues). Second, in the 1987 network, most banks with substantial international operations were tied into a single component, and every major international bank 
had a second-degree tie with another bank. AT\&T executives served on the boards of both Manufacturers Hanover and Chase Manhattan. Amoco officers served on the boards of Chase, Continental Illinois, and First Chicago. Exxon executives were on the boards of JP Morgan and Chemical, and Xerox executives were on the boards of Chase, Citicorp, and State Street Boston. By 2002, in contrast, there was not a single instance of such second-degree ties, and the overall network had become far more sparse. Global banks still had more "international” received ties than their domestic counterparts (18.4 percent foreign sales vs. 11 percent), but there were fewer of them (3.3 ties on average compared to 1.7 for domestic banks), and they did not provide conduits to other global banks.

\section{The global reach of banks after acquisition}

To what extent do global banks retain their foreign branches after they are acquired by another bank? The data in Table 3 indicate that the vast majority of foreign branches owned by banks that were acquired remained open even two years after the banks' acquisition. Of the 561 total foreign branches held within one month of a parent branch being acquired, 454 (80.9 percent) remained with the bank two full years afterward. Still, there was considerable variation in the experiences of acquired banks. Some small branch networks (such as those of Crocker National Bank and National City Bank Minneapolis) were completely shuttered, while others (including First RepublicBank Dallas and First Fidelity) were untouched. Large networks, too, saw a range of effects on the life chances of their branches. Over half of JP Morgan’s 21 foreign branches were closed within one year of its acquisition by Chase, but all but two of Bank of Boston’s 191 branches remained in operation two years after being acquired by Fleet. In all, 19 of the 26 acquired networks saw at least one branch closed within two years. 
$<$ Table 3 about here $>$

Table 4 presents data similar to those in Table 3, except that the focus is on the number of countries in which the acquired banks operated, as opposed to the number of branches. Similar to the findings in Table 3, the data here demonstrate that in the vast majority of cases, the acquired bank did not exit countries in which it had previously had branches, even two years after its acquisition by another bank. On the other hand, the foreign branch networks for 18 of the 26 acquired banks saw at least one country exited within two years. The findings in these two tables indicate that most acquired banks experienced some reduction in their foreign branching, but in most cases foreign branches remained, even after the bank was acquired.

$<$ Table 4 about here $>$

Table 5 presents data on the effect of acquisition on the global presence on bank boards. Each row of the table represents a bank acquisition. The first column (after the acquisition date) represents the pre-acquisition name of the acquired bank, followed by the number of the acquired bank's board members who were executives of non-financial corporations with more than ten percent of sales outside the U.S. one year prior to its acquisition. The next column gives the name of the bank that made the acquisition, followed by its number of pre-acquisition "global board members” (also one year prior to making the acquisition). The final column gives the name of the surviving bank subsequent to the acquisition, followed by the surviving bank's number of global board members one year subsequent to the acquisition. 
$<$ Table 5 about here $>$

The data in the table indicate that the acquired banks had slightly fewer global directors on their board than did their acquirers (2.35 vs. 2.91). This difference was not statistically significant, however. Directors with international experience on the surviving banks' boards increased to an average of 3.26 as boards were reconfigured to include members of the acquired bank. This is marginally statistically significantly different from the number of global directors of the acquired bank, $t(22)=1.74, p=.10$, but it is not statistically significantly different from the number of global directors that had been serving on the acquiring bank's board. Overall, the findings indicate that the acquisitions of banks had a detectable, but minor, effect on the banks' maintenance of their foreign branches.

\section{DISCUSSION}

In this paper we have examined the relationship between interlocking directorate networks and strategy as it pertains to the foreign branching strategies of U.S. banks. We theorized a link between the amount of international experience of a bank's board members and the size of the foreign branch network operated by the bank. We anticipated that the widespread merger movement and subsequent industry consolidation that has taken place within American banking since 1986 would be a cause of the reconfiguration of foreign branches operated by U.S. banks, and that it would do so in part through board of director networks. What we found instead was a growing disconnect between the characteristics of a bank’s board and its global strategy. We have documented several manifestations of this transformation. 
First, mergers did not lead global banks to increase the number of directors serving on their boards in a sustained manner. Some banks enlarged their boards slightly by adding select directors from the bank they acquired, while other banks constructed a post-acquisition board whose size was roughly equal to its pre-acquisition size and then populated it with an almost even split between former members of the merging banks' boards. Those banks that did increase their number of directors following an acquisition quickly reduced the size of their boards to preacquisition levels through attrition, as illustrated in the cases of Bank America (formerly NCNB and NationsBank) and JPM Chase (formerly Chemical Bank and Chase Manhattan).

Even without a sustained increase in board size, banks still had an opportunity to change the composition of their boards based on which directors they kept from the board of the acquired bank. As the banking industry consolidated, we expected to see global banks increase the number of directors with international experience serving on their boards. Yet this did not occur; the number of directors with international experience serving on global banks' boards did not increase. Even the largest global banks did not add multinational CEOs as they acquired increasingly more banks. Instead, they seem to have been operating according to an unwritten rule, or institutional logic, of board composition. Boards of post-acquisition banks appear to have been filled in an almost formulaic way: a group of top officers from major corporationsmost of them active but often one or more retired, and some with substantial international experience—plus one or two private investors, as well as public figures such as university presidents, foundation directors, and former public officials. Concentration of an industry does not therefore translate into concentration of banks' boards.

Second, and following from the findings from the previous point, the strong cluster of banks found within the interfirm network in 1987 no longer exists. By 2002 banks had become 
the sullen loaners of the corporate world. The network of director ties between banks and nonfinancial corporations, which in 1987 saw most global banks connected to at least one other global bank through second-degree ties, had devolved into a series of discrete clusters, completely disconnected from one another. Given that this network fracturing occurred during unprecedented consolidation within the banking industry, it calls into question some of the conventional wisdom regarding the concentration of power among financial firms.

Writing about the major German and American banks near the end of World War I, Lenin (1916: 31) noted that "[t]he transformation of numerous modest intermediaries into a handful of monopolists represents one of the fundamental processes in the transformation of capitalism into capitalist imperialism.” As banks became ever more concentrated, the reasonable expectation would be that the resulting banks would occupy an ever-greater role in the American, and possibly global, economy, as well as an increasingly central position in the intercorporate network. Banks did remain highly central in the U.S. network into at least the early 1980s, although their centrality did not increase over time (Mizruchi, 1982). Since then, despite the rapid concentration of the U.S. banking industry, the trend in network centrality has, if anything, been the opposite of what Lenin predicted. Not only has the centrality of global banks not increased, but it has actually declined slightly (from an average of 4.86 in eigenvector centrality in 1987 and 1992 to 3.83 in 1997 and 2002), although this decline is not statistically significant.

Third, the regional banks that bought global banks did not retrench their newly-acquired foreign networks. In several prominent instances, they kept them intact. In addition to the earlier example of Fleet Bank, NationsBank operated just five global branches upon acquiring Bank of America, but had 53 foreign branches in 1998, after the acquisition. Although NationsBank did close 14 of those branches over the next two years, this appears to have been 
done as a means of streamlining its operations, rather than as an attempt to abandon its foreign presence. As evidence of this, we note that despite its closure of individual branches, the bank withdrew completely from only one country during this retrenchment. One possible reason that these regional banks maintained the foreign presence of the banks they acquired may have been the changes in federal banking laws that were occurring during this period. The Riegle-Neal Act, passed in 1994, allowed full interstate banking (that is, banks could own branches in different states) for the first time. The lifting of this restriction opened numerous strategic possibilities to banks, and many responded by turning their attention from the local economy to economies of the region, the United States as a whole, and eventually the rest of the world.

Finally, despite the fact that the regional banks that acquired global banks maintained the latter’s foreign branches, the overall level of foreign branching has fallen to pre-1982 levels. Lenin's concern about the concentration of financial intermediaries would have led us to predict the opposite. In Lenin's view, consolidation in the banking industry should have led to an increase in large banks' export of capital, as they replace states and multilateral organizations as sources of capital for businesses and other states worldwide. One indicator of this, we have argued, would be an increase in the number of foreign branches operated by U.S. banks. Yet the bulk of the increase in foreign branching by American banks occurred in the 1960s and 1970s, and the level began to decline in the early 1980s. Although an increase did occur in the late 1990s, this was concentrated in one country—Argentina—and the banks subsequently scaled back their operations, both there and elsewhere. 


\section{CONCLUSION}

At its essence, this paper is an attempt to answer a question about a curious phenomenon in U.S. banking: Why, given the increased global activity of American non-financial corporations since 1980, did U.S. banks pull back from their involvement in foreign branching? One possible reason for this, we suggested, was the concentration of the banking industry and the concomitant acquisition of global banks by smaller banks with historically regional orientations. Our findings suggest, however, that with a few notable exceptions, the regional banks that acquired the global giants maintained the latter's foreign branches. This means that the deglobalization of U.S. banking has to be a result of factors other than the increased concentration of the industry.

One possibility that we mentioned earlier is that American banks in foreign nations were killed by their own success. In establishing a presence overseas, U.S. banks typically hired and trained bankers from the host country. These bankers, using the skills they had learned at the U.S. bank, in many cases chose to form banks of their own. The competitive advantage that they possessed as indigenous members of their societies may have made it more difficult for the American banks to compete in those markets.

We do not know how prevalent this phenomenon was, or whether it had the effect that we are suggesting. We believe that there are ways to test this argument, however. If we are correct, we might expect to observe a correlation between the prevalence of startup banks and the closure of U.S. branches, net of other factors. We could also examine the extent to which the new banks in these nations are headed by former employees of American banks located in their nations.

As we consider alternative reasons for why American banks have retrenched their foreign operations since 1980, we should not lose sight of the fact that so many of the banks that 
acquired foreign branches via the merger wave in the U.S. banking industry did not. Especially interesting is why regional banks with little experience in global branch banking, such as NationsBank and Fleet Bank, maintained almost all of their acquired foreign branching networks. Yet rather than only ask why certain banks kept their foreign branches and others did not, we can consider what this overall trend suggests about the relationship between a bank's network of directors and its strategies.

Our assumption going into this study was that a bank’s board would help shape its acquisition strategy and also its globalization strategy. In particular, the more international experience its directors have, the more extensive a bank’s foreign branch network, and the less international experience its directors have, the less likely a bank’s acquisition targets would have extensive foreign branch networks. In the latter's case, any foreign branches that were part of an acquisition would fit neither the bank's (and the board's) experience nor its identity and would be quickly jettisoned. The findings here suggest that we need to rethink these assumptions. It appears instead that banks' strategies may have been independent of the international experience of their board members and that their acquisition strategies helped shape their globalization strategies or may have even been one and the same. A regional bank may have initially viewed an acquired bank's foreign branches as unwanted baggage in the deal but then come to realize their value once it took ownership. Alternatively, a bank may have always viewed a target bank's foreign branches as an integral part of an acquisition package as it looked to expand its geographic areas of coverage. Future work is necessary to explore these alternatives, perhaps by examining written documents and speeches given by the bank’s top executives about their strategic vision. 
Finally, the decisions that banks made in constructing their post-acquisition boards leads us to speculate about the relationship between individual banks' board composition strategies and the overall shape of the directorate network. Banks historically have taken different approaches to boards than have non-financial firms, and these approaches have changed over time. But rather than simply affecting the board characteristics and network position of individual banks, these individual-level strategies have consequences for the aggregate network to the point where we could say that banks have had particular network assembly rules.

The literature on banks and their interlocks suggests that banks have used three network assembly rules that in turn have led to three distinct network signatures found in the U.S. directorate network. In the earliest period of public corporations, the U.S. directorate network was balkanized and centralized as finance capitalism dominated. Major bankers such as J.P. Morgan controlled groups of companies by placing themselves or their officers on the boards of dozens of firms (Brandeis, 1914). As finance capitalism gave way to managerial capitalism in the 1920s, the directorate network became diffuse and centralized. Banks remained the most central actors in the intercorporate network (Mizruchi, 1982) but their network assembly rules shifted. Rather than controlling financial flows through the use of sent ties, banks sought access to information that would be available via the received ties of well-connected CEOs. These CEOs were more than willing to serve on bank boards not only because bank directorships were prestigious but because their firms relied on banks for financing and the CEOs wanted to participate in decisions about capital flows (Mintz \& Schwartz, 1985). Beginning in the 1980s, however, technological and regulatory changes led firms to turn to other sources for financing and allowed commercial banks to enter other lines of business. This weakened the mutual dependence between banks and firms, and once again banks changed how they assembled their 
board networks. In this new era of shareholder capitalism, banks began to look like every other firm oriented toward increasing shareholder value. The directorate network became diffuse and decentralized as banks reduced the size of their boards and their recruiting of centrally located directors. For the first time since the rise of publicly-traded companies in the U.S., banks were no longer the center of the directorate network (Davis \& Mizruchi, 1999).

Our observation of how post-acquisition banks constructed their boards is consistent with the transformation that took place between the second and third epochs. After acquiring another bank, the surviving bank either created a board with about the same number of members as it previously had and populated it with an approximately equal mix of directors from the boards of the acquiring and acquired banks, or it kept all of its own directors and added a select few-if any-directors from the acquired bank’s board. Thus the dissolution of strong clustering in the interfirm network between 1987 and 2002 can be seen as an aggregation of the decisions by individual banks on how to compose their boards. This finding has parallels with that of Amburgey et al. (2008), who show that one basis of interfirm connection—preferential attachment—has a demonstrable effect on the structure of alliances of biotech firms. Unlike Amburgey et al., however, who found a core-periphery structure, our network reveals a group of loosely-connected clusters with no clear core.

This notion of network assembly rules suggests a re-orientation for how we think about network structure, network dynamics, and the role of strategy as these may be more intertwined than typical models of interfirm networks suggest. For instance, although networks are often modeled as exogenous entities whose properties influence the decisions of individual actors, in reality network properties are often endogenous with respect to the actors, who strategically 
construct their ties depending on their own characteristics and their partners' characteristics, including, importantly, to whom their partners are already connected.

We also need to pay attention to constraints on networking. Especially in social networks that require face-to-face communication such as boards of directors, there are social, organizational, and even physical constraints on how large a network should be. As Doreian (2008) suggests, there are liabilities to an actor of having too many ties. This point can be illustrated by the case of First RepublicBank, which thought that 46 directors would make a fine board until it discovered that the directors could not all fit in the board room (Apcar, 1988). Constraints may also involve filling specific roles, as we saw banks do when filling their postacquisition boards. Even though banks already had begun to appoint fewer centrally located directors, acquisitions were an easy opportunity to bring aboard these "celebrity CEOs." For the most part, though, banks chose not to. A thorough understanding of the properties and consequences of the macro network structure thus results from considering both the decisions by and properties of individual-level actors and the interactions between individual actors and the environment (Schelling, 1978). Acknowledging these complexities and maintaining focus on both individual and network levels simultaneously would be a step in this direction. 


\section{ACKNOWLEDGMENTS}

This chapter was written while the first author was at the University of Michigan. Research was supported by the Rackham Graduate School, the Stephen M. Ross School of Business, and the College of Literature, Science, and the Arts, all at the University of Michigan. The chapter benefited from comments by participants at the Economic Sociology Seminar at the University of Michigan and the Network Strategy Conference held at the Rotman School of Management, University of Toronto. 


\section{APPENDIX A}

Mergers between banks where the acquired bank operated at least one foreign branch (excluding the

Bahamas and the Cayman Islands) at the time of acquisition, 1986-2004.

\begin{tabular}{|c|c|c|c|}
\hline Merger Date & Acquired Bank & Acquiring Bank & Surviving Bank \\
\hline $5 / 31 / 1986$ & Crocker National Corporation & Wells Fargo \& Co & Wells Fargo \& Co \\
\hline 6/6/1987 & InterFirst Corporation & RepublicBank Corporation & First RepublicBank Corporation \\
\hline $7 / 30 / 1988$ & First RepublicBank Corp & NCNB Corporation & NCNB Corporation \\
\hline $1 / 1 / 1989$ & Rainier Bancorporation & Security Pacific Bancorporation & Security Pacific Bancorporation \\
\hline 10/6/1989 & Irving Bank Corporation & Bank of New York Co & Bank of New York Co \\
\hline $3 / 5 / 1990$ & First Pennsylvania Corp & CoreStates Financial Corp & CoreStates Financial Corp \\
\hline $7 / 14 / 1991$ & Bank of New England & Fleet/Norstar Financial Group & Fleet/Norstar Financial Group \\
\hline 12/31/1991 & Manufacturers Hanover Corp & Chemical Banking Corp & Chemical Banking Corp \\
\hline 4/22/1992 & Security Pacific Bancorporation & BankAmerica Corp & BankAmerica Corp \\
\hline $5 / 21 / 1993$ & Boston Co & Mellon Bank Corporation & Mellon Bank Corporation \\
\hline 9/1/1994 & Continental Bank Corp & BankAmerica Corp & BankAmerica Corp \\
\hline $12 / 1 / 1995$ & NBD Bancorp & First Chicago Corp & First Chicago NBD Corporation \\
\hline $1 / 2 / 1996$ & First Fidelity Bancorporation & First Union Corp & First Union Corp \\
\hline 3/31/1996 & Chase Manhattan Corp & Chemical Banking Corp & Chase Manhattan Corp \\
\hline $4 / 1 / 1996$ & First Interstate Bancorporation & Wells Fargo \& Co & Wells Fargo \& Co \\
\hline $4 / 28 / 1998$ & CoreStates Financial Corp & First Union Corp & First Union Corp \\
\hline 9/30/1998 & BankAmerica Corp & NationsBank Corp & Bank of America Corp \\
\hline $10 / 2 / 1998$ & First Chicago NBD Corporation & Bank One Corp & Bank One Corp \\
\hline 10/1/1999 & BankBoston & Fleet Financial Group & FleetBoston Financial Corp \\
\hline $3 / 1 / 2000$ & Pacific Bank NA & City National Corporation & City National Corporation \\
\hline $12 / 31 / 2000$ & J.P. Morgan \& Co. Incorporated & Chase Manhattan Corp & J.P. Morgan Chase \& Co \\
\hline $8 / 1 / 2001$ & National City Bancorporation & Marshall \& Isley Corporation & Marshall \& Isley Corporation \\
\hline 9/1/2001 & Wachovia Corp & First Union Corp & Wachovia Corp \\
\hline $4 / 1 / 2004$ & FleetBoston & Bank of America Corp & Bank of America Corp \\
\hline $5 / 14 / 2005$ & Riggs National Corporation & PNC Financial Services Group & PNC Financial Services Group \\
\hline
\end{tabular}




\section{REFERENCES}

Amburgey, T.L., Al-Laham, A., Tzabbar, D., and Aharonson, B. (2008). "The Structural Evolution of Multiplex Organizational Networks: Research and Commerce in Biotechnology.” In J.A.C. Baum and T.J. Rowley (eds.), Network Strategy: Advances in Strategic Management, 25 (pp. \#\#-\#\#). Oxford UK: JAI/Elsevier.

Apcar, L. M. (1988, May 2). First RepublicBank to cut board size, oust prominent members of old guard. Wall Street Journal, p. 9.

Armijo, L. E. (1999). Introduction and Overview. In L.E. Armijo (ed.), Financial Globalization and Democracy in Emerging Markets (pp. 1-14). New York: St. Martin’s.

Arrighi, G. and Silver, B. J. (1999). Hegemonic transitions: past and present. Political Power and Social Theory 13, 239-275.

Baker, J. C. and Bradford, M. G. (1974). American Banks Abroad: Edge Act Companies and Multinational Banking. New York: Praeger.

Brandeis, L. (1914). Other Peoples’ Money: and How the Bankers Use It. New York: Frederick A. Stokes.

Braudal, F. (1984). Civilization \& Capitalism 15th-18th Century, Volume 3: The Perspective of the World. New York: Harper \& Row.

Brimmer, A. F. (1973). American International Banking: Trends and Prospects. Presented at the 51st Annual Meeting of the Bankers’ Association for Foreign Trade, Boca Raton, Florida.

Brimmer, A. F. and Dahl, F. R. (1975). Growth of American international banking: Implications for public policy. Journal of Finance 30, 341-363.

Conyon, M. J. and Muldoon, M. R. “Ownership and control: A small-world analysis.” In J.A.C. Baum and T.J. Rowley (eds.), Network Strategy: Advanced in Strategic Management, 25 (pp. \#\#-\#\#). Oxford UK: JAI/Elsevier.

Davis, G. F. (1991). Agents without principles? The spread of the poison pill through the intercorporate network. Administrative Science Quarterly 36, 583-613.

Davis, G. F. and Mizruchi, M. S. (1999). The money center cannot hold: Commercial banks in the U.S. system of corporate governance. Administrative Science Quarterly 44, 215-239.

Dombrowski, P. (1996). Policy Responses to the Globalization of American Banking. Pittsburgh: University of Pittsburgh Press.

Doreian, P. (2008). “Actor Utilities, Strategic Action, and Network Evolution.” In J.A.C. Baum and T.J. Rowley (eds.), Network Strategy: Advances in Strategic Management, 25 (pp. \#\#-\#\#). Oxford UK: JAI/Elsevier. 
Hallow, M. J. S. (1993). Over There: American Banks Abroad. New York: Garland Publishing.

Haunschild, P. R. (1993). Interorganizational imitation: The impact of interlocks on corporate acquisition activity. Administrative Science Quarterly 38, 564-592.

Henisz, W. J. and Delios, A. (2001). Uncertainty, imitation, and plant location: Japanese multinational corporations, 1990-1996. Administrative Science Quarterly 46, 443-475.

Hite, J.M. (2008). “The Dynamic Evolution of Network Ties: Navigating Multi-Dimensionality, Dyadic Contexts, Bounded Agency and Strategic Action.” In J.A.C. Baum and T.J. Rowley (eds.), Network Strategy: Advances in Strategic Management, 25 (pp. \#\#-\#\#). Oxford UK: JAI/Elsevier.

Larosiere, J. de. (2005). From Mexico to Argentina: What Have We Learned from Two Decades of Debt Crises? Princeton Institute for International and Regional Studies, Monograph Series. Number 3. Princeton University.

Lenin, V.I. (1939; orig. 1916). Imperialism: The Highest Stage of Capitalism. New York: International Publishers.

Manzocchi, S. (1999). Capital flows to developing economies throughout the $20^{\text {th }}$ century. In L.E. Armijo (ed.), Financial Globalization and Democracy in Emerging Markets (pp. 51-73). New York: St. Martin's.

Marquis, C. and Lounsbury, M. (2007). Vive la Résistance: Competing logics and the consolidation of U.S. community banking. Academy of Management Journal 50, 799-820.

Martin, X., Swaminathan, A., and Mitchell, W. (1998). Organizational evolution in the interorganizational environment: Incentives and constraints on international expansion strategy. Administrative Science Quarterly 43, 566-601.

Mintz, B. and Schwartz, M. (1985). The Power Structure of American Business. Chicago: University of Chicago Press.

Mizruchi, M. S. (1982). The American Corporate Network, 1904-1974. Beverly Hills: Sage Publications.

Mizruchi, M. S. (1996). What do interlocks do? An analysis, critique, and assessment of research on interlocking directorates. Annual Review of Sociology 22, 271-298.

Robinson, S. W., Jr. (1972). Multinational Banking. Leiden: A.W. Sijthoff.

Schelling, T. C. (1978). Micromotives and Macrobehavior. New York: W. W. Norton.

Smith, R. C. (1989). The Global Bankers. New York: Dutton.

Sullivan, D. (1994). Measuring the degree of internationalization of a firm. Journal of International Business Studies 25, 325-342. 
Useem, M. (1984). The Inner Circle. New York: Oxford University Press.

World Bank. (1997). Private Capital Flows to Developing Countries: The Road to Financial Integration. Oxford, UK: Oxford University Press. 
Figure 1. Cumulative ownership of foreign branches by U.S. banks, 1986-2004

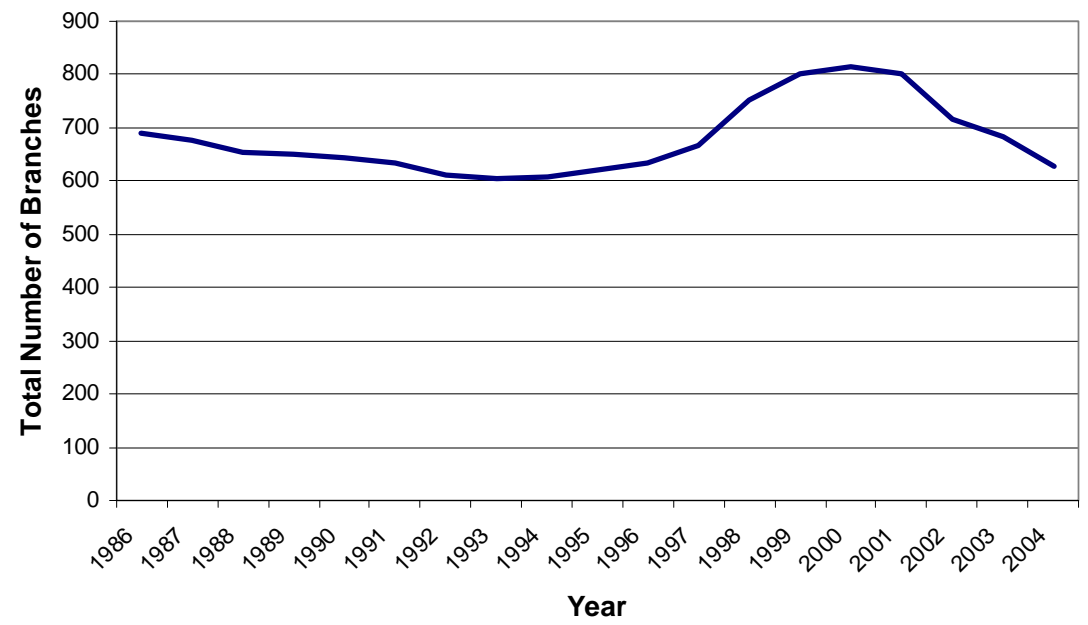

Figure 3. Number of countries with at least 1 branch of U.S. bank, 1986-2004

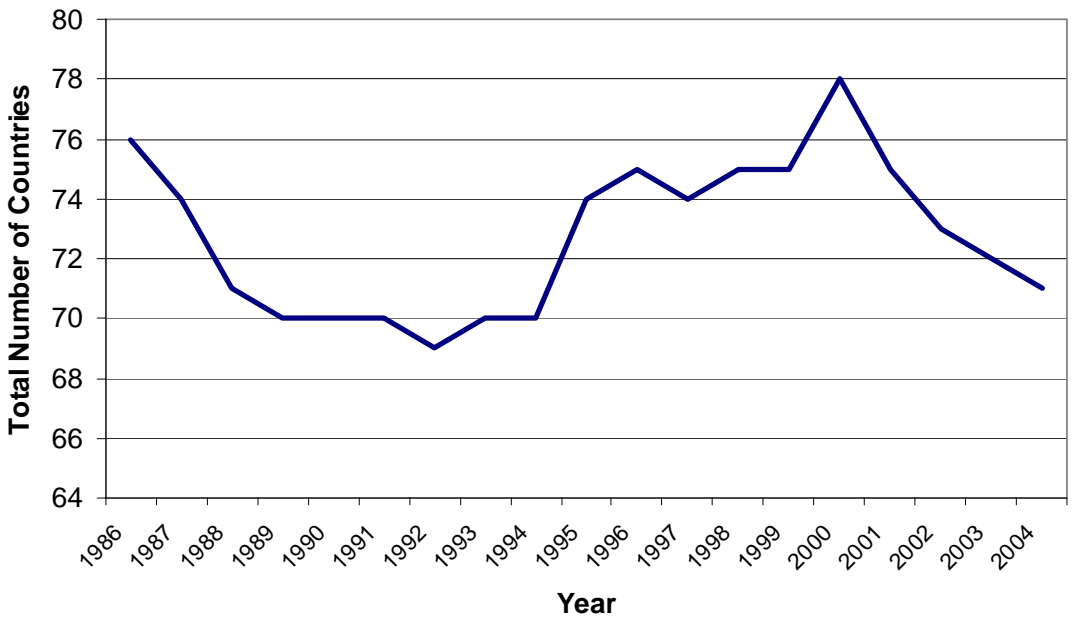

Figure 2. Number of U.S. banks operating foreign branches, 1986-2004

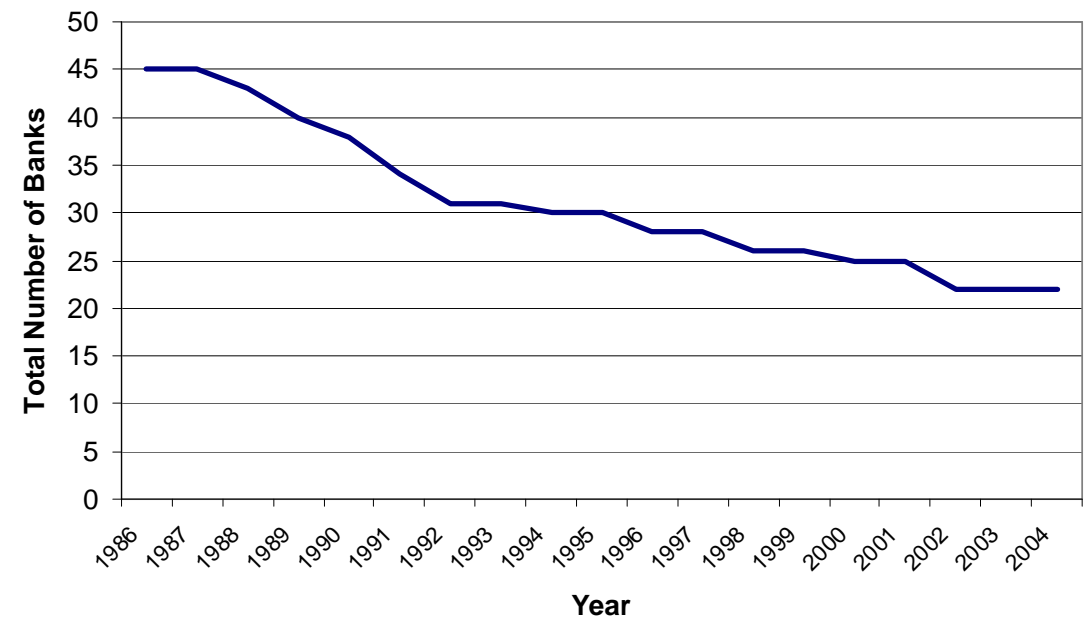

Figure 4. Percentage of all foreign branches owned by the 3 most global U.S. banks, 1986-2004

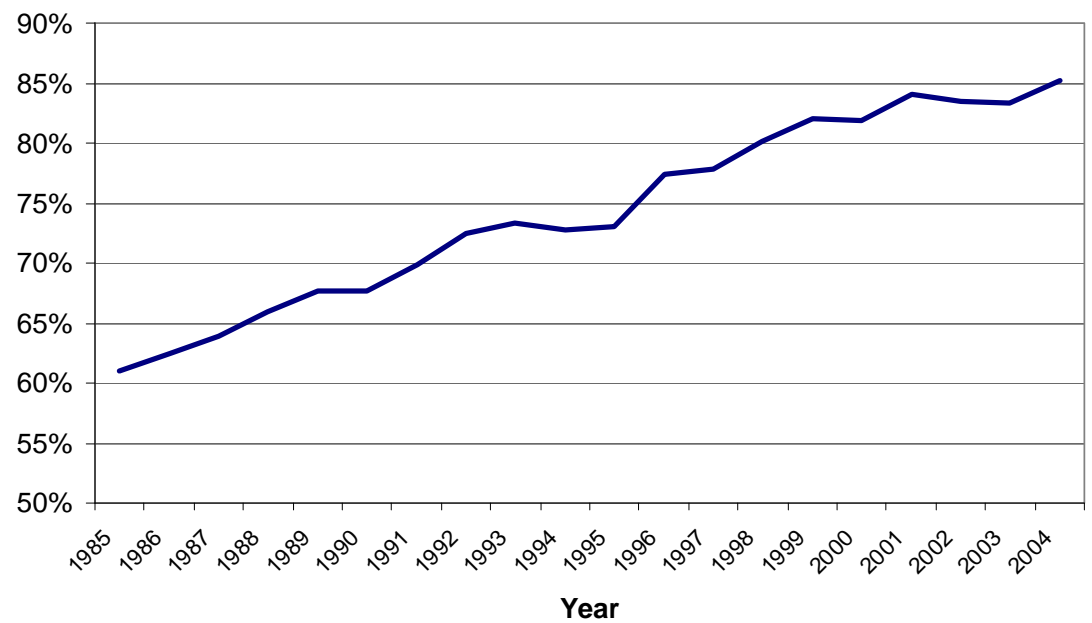


Figure 5. Bank consolidation, 1990-2005. (Numbers in circles are ranks in 1990.)

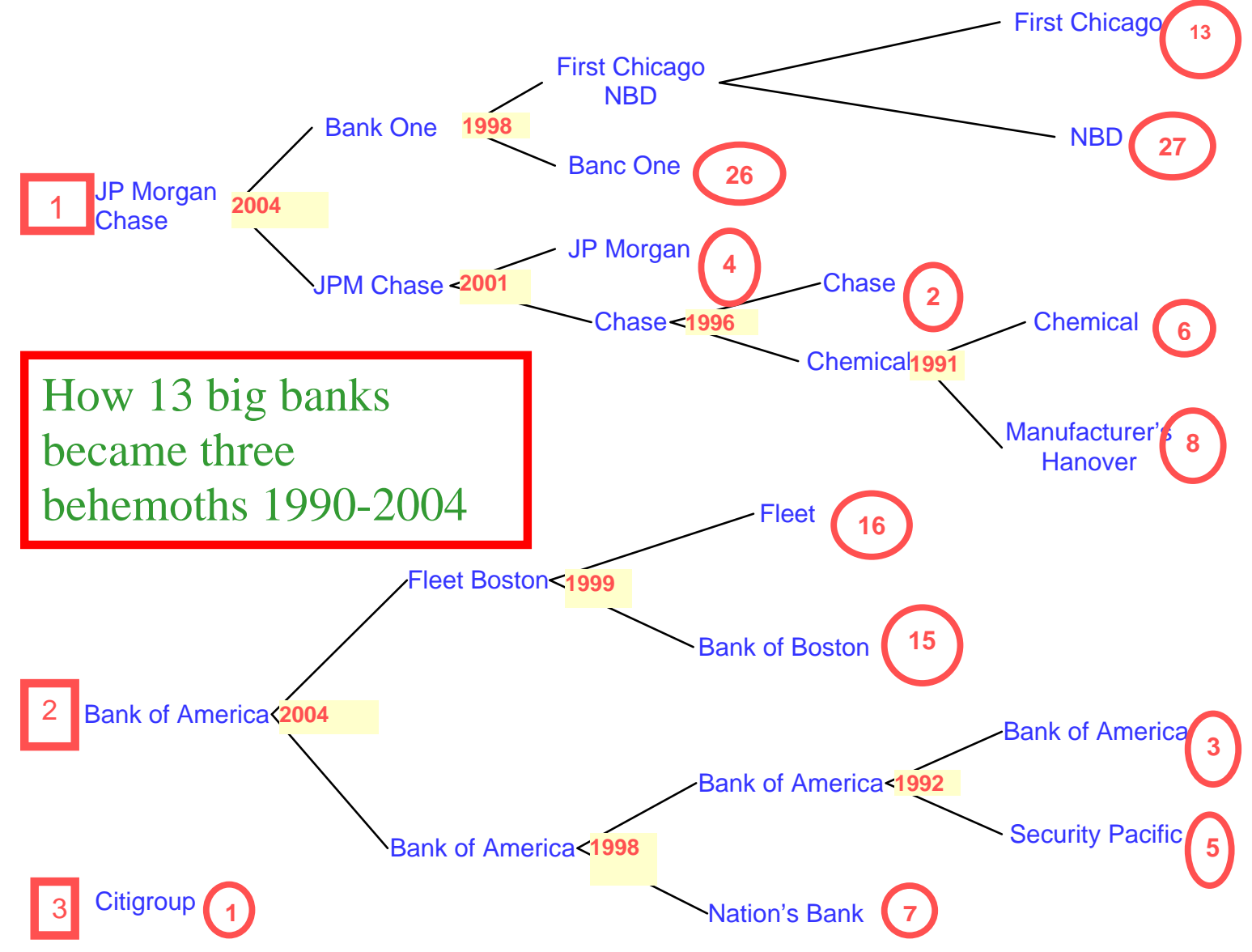


Figure 6. Board Composition of Bank of America (previous names include North Carolina National Bank, NCNB, and NationsBank), 1986-2007

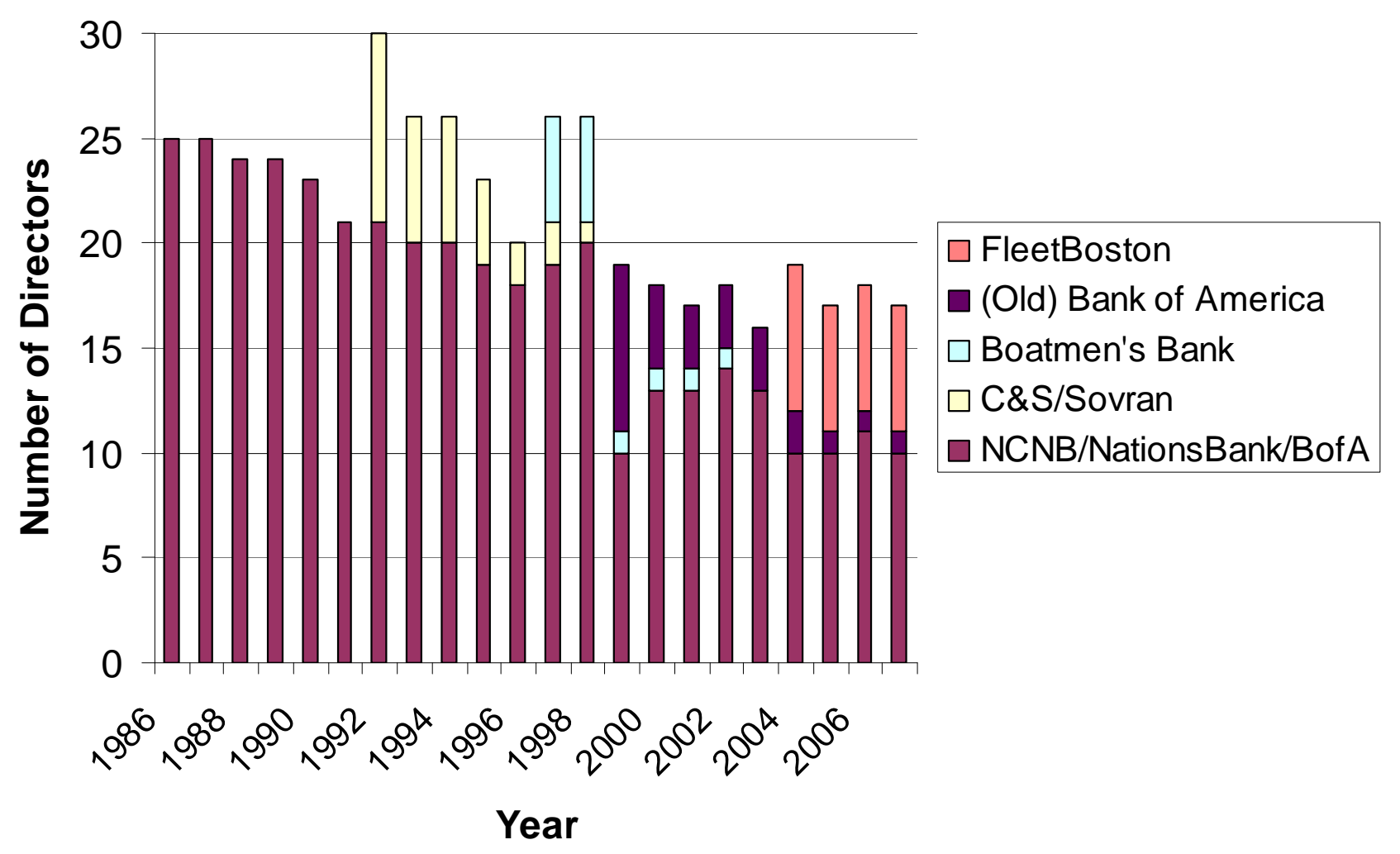


Figure 7. Board Composition of JPM Chase (previous names include Chemical Bank and Chase Manhattan), 1986-2007

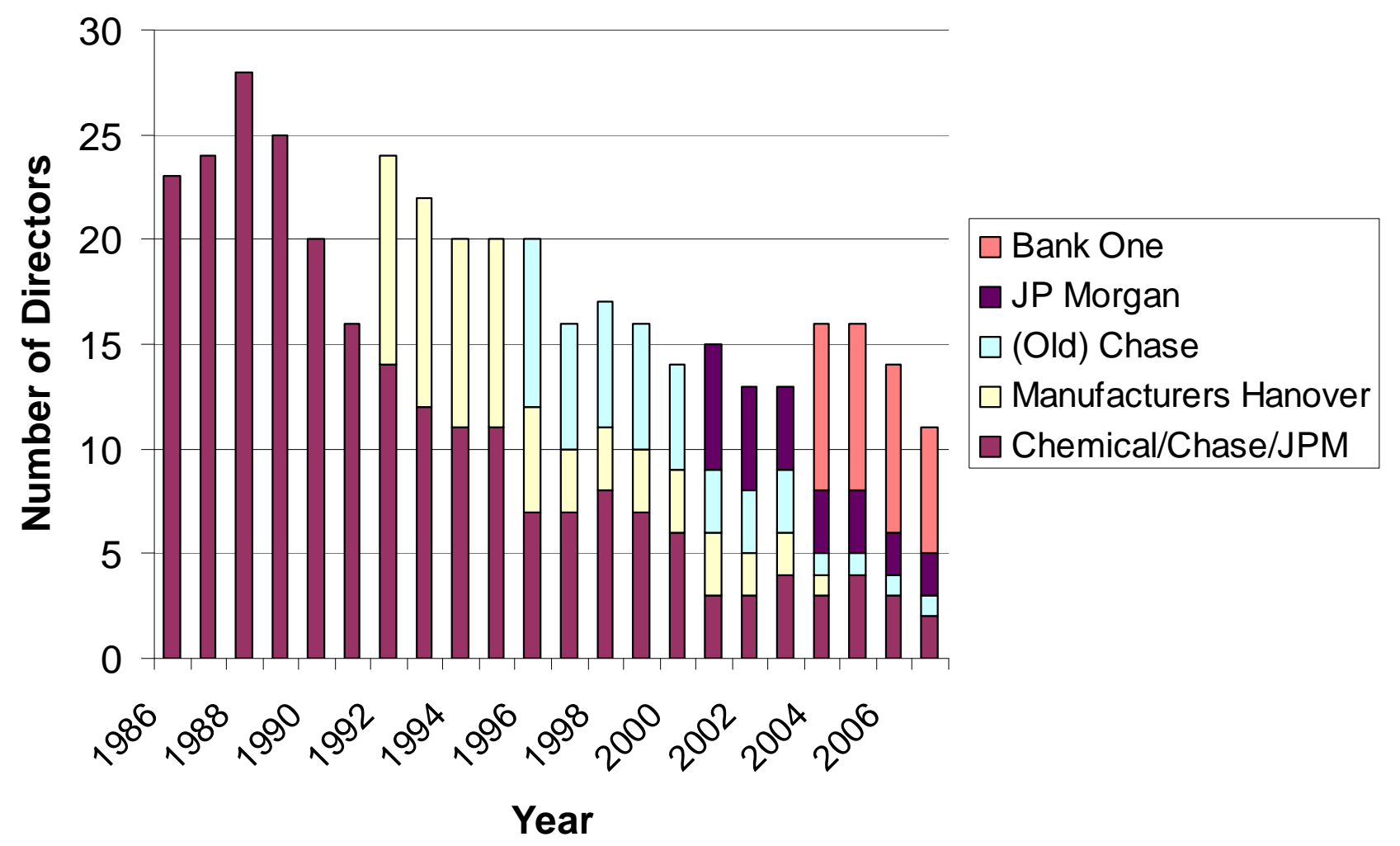


Figure 8. Received tie network for global banks, 1987. (Banks in red, non-banks in blue. Node size represents magnitude of international operations.)

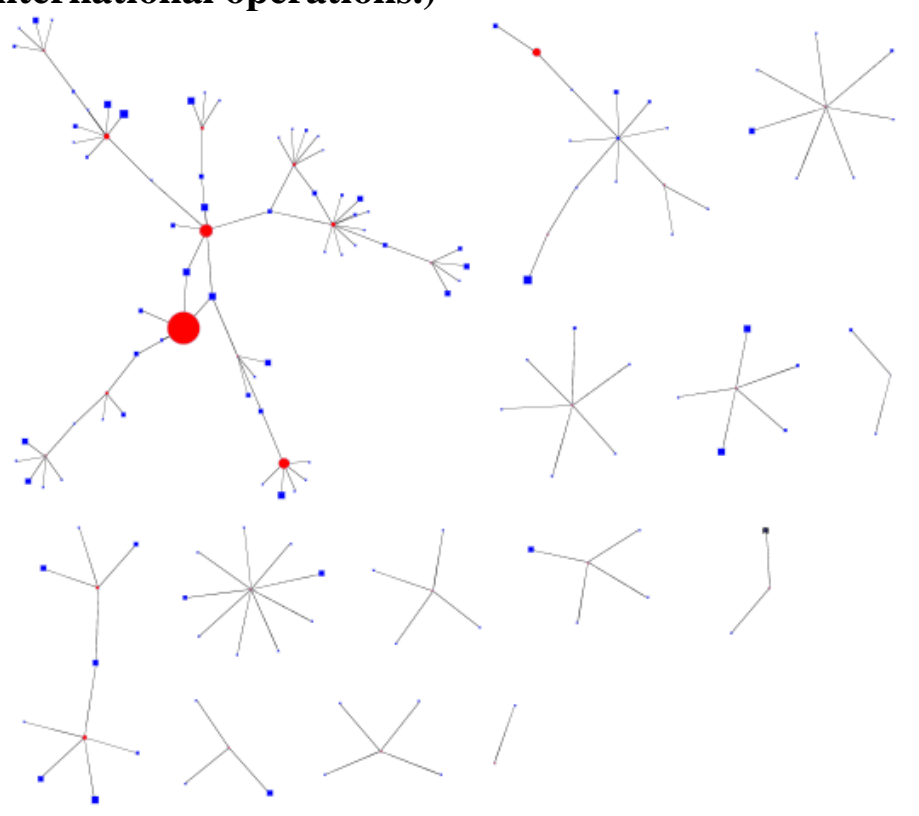


Figure 9. Received tie network for global banks, 2002. (Banks in red, non-banks in blue. Node size represents magnitude of international operations.)

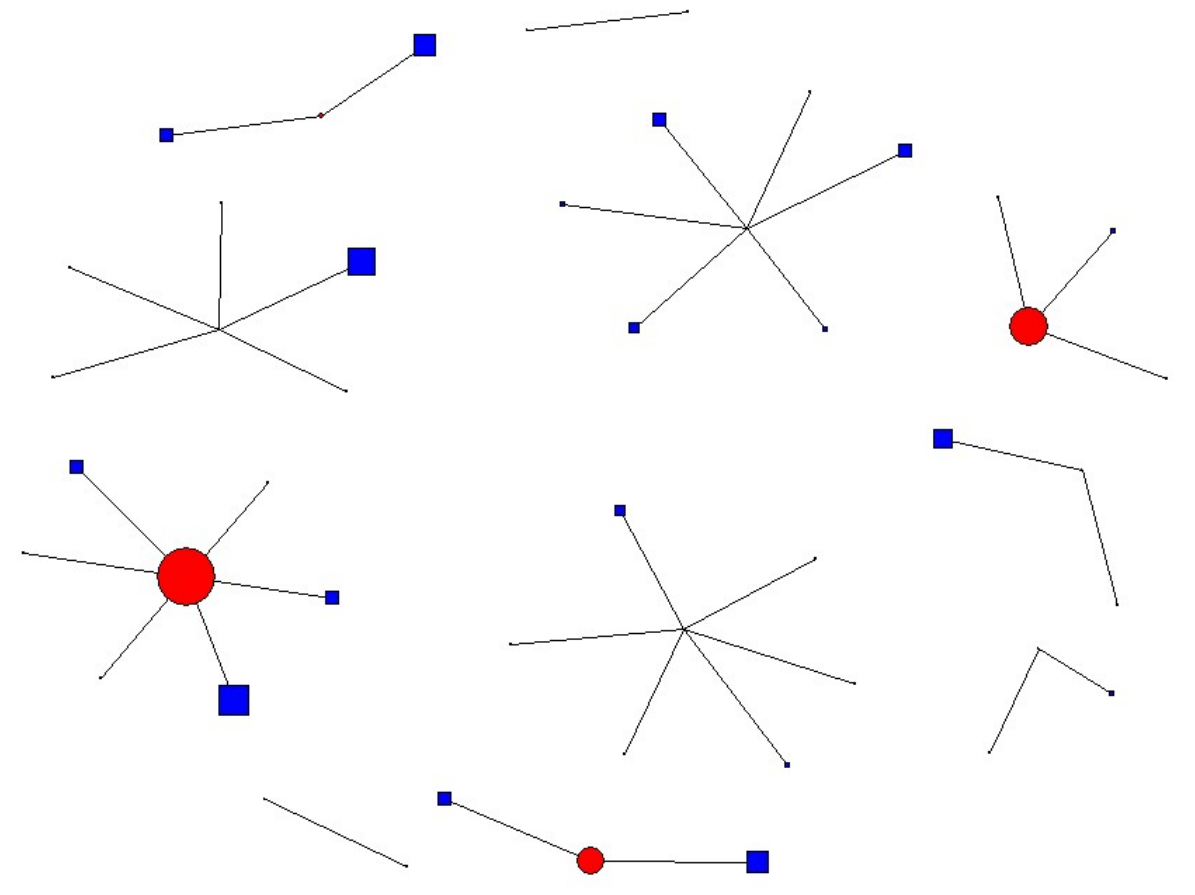


Table 1. Countries entered by U.S. banks, by year

\begin{tabular}{ll}
\hline Year $^{*}$ & Countries Entered \\
\hline 1987 & China \\
& New Zealand \\
\hline 1990 & Costa Rica \\
\hline 1993 & Fiji \\
\hline 1994 & Australia \\
& Nicaragua \\
\hline 1995 & Bangladesh \\
& Mexico \\
& Russia \\
& South Africa \\
& Vietnam \\
\hline 1996 & Lebanon \\
& Netherlands Antilles \\
\hline 1998 & Algeria \\
& Cameroon \\
\hline 2000 & Bulgaria \\
& Canada \\
& Israel \\
\hline
\end{tabular}

* - Year in which a U.S. bank opened a branch in a country when there had previously been no branches of U.S. banks in that country 
Table 2. Board size and centrality of non-financials, banks, and global banks

Comparisons of boards: median values of board size, eigenvector centrality, and degree centrality, 1987-2002

\begin{tabular}{llrrrr} 
& & $\mathbf{1 9 8 7}$ & $\mathbf{1 9 9 2}$ & $\mathbf{1 9 9 7}$ & $\mathbf{2 0 0 2}$ \\
\hline Non-financials & Size & 8 & 8 & 7 & 8 \\
& Eigenvector centrality & 0.14 & 0.19 & 0.09 & 0.18 \\
& Degree centrality & 2 & 2 & 3 & 3 \\
\hline Banks & Size & 12 & 11 & 10 & 10 \\
& Eigenvector centrality & 0.14 & 0.08 & 0.05 & 0.04 \\
& Degree centrality & 1 & 1 & 0 & 0 \\
\hline Global banks & Size & 18 & 17 & 16 & 17 \\
& Eigenvector centrality & 4.59 & 5.13 & 3.57 & 4.1 \\
& Degree centrality & 21.5 & 20 & 18 & 18.5
\end{tabular}


Table 3. Surviving branches of an acquired bank before and after acquisition

\begin{tabular}{|c|c|c|c|c|c|c|c|c|c|}
\hline Acq date & Acquired bank name & $\begin{array}{c}30 \text { days } \\
\text { prior }\end{array}$ & $\begin{array}{c}\text { Day of } \\
\text { Acq. }\end{array}$ & $\begin{array}{c}30 \text { days } \\
\text { after }\end{array}$ & $\begin{array}{c}60 \text { days } \\
\text { after }\end{array}$ & $\begin{array}{c}90 \text { days } \\
\text { after }\end{array}$ & $\begin{array}{c}180 \text { days } \\
\text { after }\end{array}$ & $\begin{array}{c}1 \text { year } \\
\text { after }\end{array}$ & $\begin{array}{c}2 \text { years } \\
\text { after }\end{array}$ \\
\hline $5 / 31 / 1986$ & CROCKER NATIONAL BANK & 1 & 1 & 1 & & & & & \\
\hline 6/6/1987 & INTERFIRST BK DALLAS NA & 3 & 3 & & & & & & \\
\hline 7/30/1988 & FIRST REPUBLICBANK DALLAS & 2 & 2 & 2 & 2 & 2 & 2 & 2 & 2 \\
\hline 1/1/1989 & RAINIER NB & 1 & 1 & 1 & 1 & 1 & 1 & 1 & 1 \\
\hline 10/7/1989 & IRVING TC & 9 & 9 & 9 & 9 & 9 & 9 & 8 & 8 \\
\hline 3/5/1990 & FIRST PENNSYLVANIA BK NA & 1 & 1 & 1 & 1 & 1 & 1 & 1 & 1 \\
\hline $7 / 14 / 1991$ & NEW BANK OF NEW ENGLAND NA & 1 & 1 & 1 & 1 & 1 & 1 & 1 & 1 \\
\hline 12/31/1991 & MANUFACTURERS HAN TC & 27 & 27 & 27 & 27 & 27 & 21 & 21 & 21 \\
\hline 4/22/1992 & SECURITY PACIFIC NB & 9 & 9 & 2 & 2 & 2 & 2 & 2 & 2 \\
\hline $5 / 21 / 1993$ & BOSTON SAFE DEPOSIT \& TC & 1 & 1 & 1 & 1 & 1 & 1 & 1 & 1 \\
\hline 9/1/1994 & CONTINENTAL BK & 6 & 6 & 5 & 5 & 5 & 3 & 3 & 2 \\
\hline $12 / 1 / 1995$ & NBD BANK & 7 & 7 & 7 & 7 & 5 & 3 & 3 & 3 \\
\hline 1/2/1996 & FIRST FIDELITY BK NA & 1 & 1 & 1 & 1 & 1 & 1 & 1 & 1 \\
\hline 3/31/1996 & CHASE MANHATTAN BK NA & 53 & 53 & 53 & 53 & 53 & 42 & 42 & 39 \\
\hline 4/1/1996 & FIRST INTERSTATE BK OF CA & 1 & 1 & & & & & & \\
\hline 4/28/1998 & CORESTATES BANK NA & 5 & 5 & 4 & 4 & 4 & 4 & 4 & 4 \\
\hline 7/23/1998 & BANK OF AMER NT\&SA & 42 & 41 & 41 & 41 & 41 & 41 & 41 & 33 \\
\hline $10 / 2 / 1998$ & FIRST NB OF CHICAGO & 10 & 10 & 10 & 10 & 10 & 10 & 10 & 10 \\
\hline 10/1/1999 & BANKBOSTON NA & 191 & 191 & 191 & 191 & 191 & 191 & 191 & 189 \\
\hline 12/31/1999 & REPUBLIC NB OF NY & 10 & 10 & 10 & 10 & 10 & 10 & 8 & 5 \\
\hline $3 / 1 / 2000$ & PACIFIC BK NA & 1 & 1 & & & & & & \\
\hline $12 / 31 / 2000$ & MORGAN GUARANTY TC & 21 & 21 & 21 & 21 & 21 & 21 & 10 & 9 \\
\hline 8/1/2001 & NATIONAL CITY BK MINNEAPOLIS & 1 & 1 & 1 & 1 & 1 & & & \\
\hline $9 / 1 / 2001$ & WACHOVIA BK NA & 1 & 1 & 1 & 1 & 1 & 1 & & \\
\hline $4 / 1 / 2004$ & FLEET NA BK & 155 & 155 & 155 & 155 & 155 & 155 & 155 & 122 \\
\hline $5 / 14 / 2005$ & RIGGS BK NA & 1 & & & & & & & \\
\hline
\end{tabular}


Table 4. Global footprint of acquired bank before and after acquisition (i.e., the number of countries spanned by the acquired banks' branches)

\begin{tabular}{|c|c|c|c|c|c|c|c|c|c|}
\hline Acq date & Acquired bank name & $\begin{array}{c}30 \text { days } \\
\text { prior }\end{array}$ & $\begin{array}{c}\text { Day of } \\
\text { Acq. }\end{array}$ & $\begin{array}{c}30 \text { days } \\
\text { after }\end{array}$ & $\begin{array}{c}60 \text { days } \\
\text { after }\end{array}$ & $\begin{array}{c}90 \text { days } \\
\text { after }\end{array}$ & $\begin{array}{c}180 \text { days } \\
\text { after }\end{array}$ & $\begin{array}{l}1 \text { year } \\
\text { after }\end{array}$ & $\begin{array}{c}2 \text { years } \\
\text { after }\end{array}$ \\
\hline $5 / 31 / 1986$ & CROCKER NATIONAL BANK & 1 & 1 & 1 & & & & & \\
\hline 6/6/1987 & INTERFIRST BK DALLAS NA & 3 & 3 & & & & & & \\
\hline $7 / 30 / 1988$ & FIRST REPUBLICBANK DALLAS & 2 & 2 & 2 & 2 & 2 & 2 & 2 & 2 \\
\hline 1/1/1989 & RAINIER NB & 1 & 1 & 1 & 1 & 1 & 1 & 1 & 1 \\
\hline 10/7/1989 & IRVING TC & 8 & 8 & 8 & 8 & 8 & 8 & 7 & 7 \\
\hline 3/5/1990 & FIRST PENNSYLVANIA BK NA & 1 & 1 & 1 & 1 & 1 & 1 & 1 & 1 \\
\hline 7/14/1991 & NEW BANK OF NEW ENGLAND NA & 1 & 1 & 1 & 1 & 1 & 1 & 1 & 1 \\
\hline 12/31/1991 & MANUFACTURERS HAN TC & 17 & 17 & 17 & 17 & 17 & 16 & 16 & 16 \\
\hline 4/22/1992 & SECURITY PACIFIC NB & 8 & 8 & 2 & 2 & 2 & 2 & 2 & 2 \\
\hline $5 / 21 / 1993$ & BOSTON SAFE DEPOSIT \& TC & 1 & 1 & 1 & 1 & 1 & 1 & 1 & 1 \\
\hline 9/1/1994 & CONTINENTAL BK & 6 & 6 & 5 & 5 & 5 & 3 & 3 & 2 \\
\hline 12/1/1995 & NBD BANK & 5 & 5 & 5 & 5 & 3 & 2 & 2 & 2 \\
\hline 1/2/1996 & FIRST FIDELITY BK NA & 1 & 1 & 1 & 1 & 1 & 1 & 1 & 1 \\
\hline 3/31/1996 & CHASE MANHATTAN BK NA & 29 & 29 & 29 & 29 & 29 & 26 & 26 & 25 \\
\hline 4/1/1996 & FIRST INTERSTATE BK OF CA & 1 & 1 & & & & & & \\
\hline $4 / 28 / 1998$ & CORESTATES BANK NA & 5 & 5 & 4 & 4 & 4 & 4 & 4 & 4 \\
\hline $7 / 23 / 1998$ & BANK OF AMER NT\&SA & 27 & 27 & 27 & 27 & 27 & 27 & 27 & 26 \\
\hline $10 / 2 / 1998$ & FIRST NB OF CHICAGO & 8 & 8 & 8 & 8 & 8 & 8 & 8 & 8 \\
\hline 10/1/1999 & BANKBOSTON NA & 16 & 16 & 16 & 16 & 16 & 16 & 16 & 16 \\
\hline 12/31/1999 & REPUBLIC NB OF NY & 9 & 9 & 9 & 9 & 9 & 9 & 7 & 4 \\
\hline $3 / 1 / 2000$ & PACIFIC BK NA & 1 & 1 & & & & & & \\
\hline $12 / 31 / 2000$ & MORGAN GUARANTY TC & 19 & 19 & 19 & 19 & 19 & 19 & 9 & 8 \\
\hline 8/1/2001 & NATIONAL CITY BK MINNEAPOLIS & 1 & 1 & 1 & 1 & 1 & & & \\
\hline $9 / 1 / 2001$ & WACHOVIA BK NA & 1 & 1 & 1 & 1 & 1 & 1 & & \\
\hline 4/1/2004 & FLEET NA BK & 13 & 13 & 13 & 13 & 13 & 13 & 13 & 5 \\
\hline $5 / 14 / 2005$ & RIGGS BK NA & 1 & & & & & & & \\
\hline
\end{tabular}


Table 5. Number of received ties from firms with at least ten percent international sales for acquired and acquiring banks (1 year before the acquistion) and the surviving bank ( 1 year after the acquistion)

\begin{tabular}{|c|c|c|c|c|c|c|}
\hline Acq. Date & Acquired Bank & $\#$ & Acquiring Bank & $\#$ & Surviving Bank & $\#$ \\
\hline $5 / 31 / 1986$ & CROCKER NATIONAL CORPORATION & 1 & WELLS FARGO \& CO & 1 & WELLS FARGO \& CO & 1 \\
\hline 6/6/1987 & INTERFIRST CORPORATION & 2 & FIRST REPUBLICBANK CORPORATION & 0 & FIRST REPUBLICBANK CORPORATION & 0 \\
\hline 1/1/1989 & RAINIER BANCORPORATION & 0 & SECURITY PACIFIC BANCORPORATION & 3 & SECURITY PACIFIC BANCORPORATION & 5 \\
\hline 10/7/1989 & IRVING BANK CORP & 1 & BANK OF NEW YORK COMPANY & 8 & BANK OF NEW YORK COMPANY & 8 \\
\hline 3/5/1990 & FIRST PENNSYLVANIA CORP & 2 & CORESTATES FINANCIAL CORP & 6 & CORESTATES FINANCIAL CORP & 2 \\
\hline $7 / 14 / 1991$ & BANK OF NEW ENGLAND (FAILED) & 5 & FLEET/NORSTAR FINANCIAL GROUP & 1 & FLEET/NORSTAR FINANCIAL GROUP & 1 \\
\hline 12/31/1991 & MANUFACTURERS HANOVER CORP & 4 & CHEMICAL BANKING CORP & 4 & CHEMICAL BANKING CORP & 4 \\
\hline 4/22/1992 & SECURITY PACIFIC BANCORPORATION & 3 & BANKAMERICA CORP & 3 & BANKAMERICA CORP & 6 \\
\hline 9/1/1994 & CONTINENTAL BANK CORP & 2 & BANKAMERICA CORP & 2 & BANKAMERICA CORP & 2 \\
\hline $12 / 1 / 1995$ & NBD BANCORP & 6 & FIRST CHICAGO CORP & 7 & FIRST CHICAGO NBD CORPORATION & 6 \\
\hline $1 / 2 / 1996$ & FIRST FIDELITY BANCORPORATION & 2 & FIRST UNION CORP & 1 & FIRST UNION CORP & 2 \\
\hline 3/31/1996 & CHASE MANHATTAN CORP & 3 & CHEMICAL BANKING CORP & 4 & CHASE MANHATTAN CORP & 7 \\
\hline 4/1/1996 & FIRST INTERSTATE BANCORPORATION & 2 & WELLS FARGO \& CO & 1 & WELLS FARGO \& CO & 3 \\
\hline $4 / 28 / 1998$ & CORESTATES FINANCIAL CORP & 2 & FIRST UNION CORP & 3 & FIRST UNION CORP & 3 \\
\hline $7 / 23 / 1998$ & BANKAMERICA CORP & 2 & NATIONSBANK CORP & 5 & BANK OF AMERICA CORP & 3 \\
\hline $10 / 2 / 1998$ & FIRST CHICAGO NBD CORPORATION & 4 & BANK ONE CORP & 1 & BANK ONE CORP & 2 \\
\hline $10 / 1 / 1999$ & BANKBOSTON & 1 & FLEET FINANCIAL GROUP & 2 & FLEETBOSTON FNCL CORP & 2 \\
\hline $3 / 1 / 2000$ & PACIFIC BANK NA & 0 & CITY NATIONAL CORPORATION & 1 & CITY NATIONAL CORPORATION & 1 \\
\hline $12 / 31 / 2000$ & J.P. MORGAN \& CO. INCORPORATED & 8 & CHASE MANHATTAN CORP & 4 & JP MORGAN CHASE \& CO & 6 \\
\hline $8 / 1 / 2001$ & NATIONAL CITY BANCORPORATION & 0 & MARSHALL \& ISLEY CORPORATION & 0 & MARSHALL \& ISLEY CORPORATION & 1 \\
\hline $9 / 1 / 2001$ & WACHOVIA CORP & 3 & FIRST UNION CORP & 2 & WACHOVIA CORP & 4 \\
\hline $4 / 1 / 2004$ & FLEETBOSTON & 1 & BANK OF AMERICA CORP & 2 & BANK OF AMERICA CORP & 1 \\
\hline \multirow[t]{4}{*}{$5 / 14 / 2005$} & RIGGS NATIONAL CORPORATION & 0 & PNC FINANCIAL SERVICES GROUP & 6 & PNC FINANCIAL SERVICES GROUP & 5 \\
\hline & MEAN & 2.35 & MEAN & 2.91 & MEAN & 3.26 \\
\hline & MEDIAN & 2 & MEDIAN & 2 & MEDIAN & 3 \\
\hline & STDEV & 2.01 & STDEV & 2.25 & STDEV & 2.24 \\
\hline
\end{tabular}

